\title{
Erratum to: Birt-Hogg-Dubé syndrome: from gene discovery to molecularly targeted therapies
}

\author{
Laura S. Schmidt
}

Published online: 8 January 2013

(C) Springer Science+Business Media Dordrecht 2013

\section{Erratum to: Familial Cancer}

\section{DOI 10.1007/s10689-012-9574-y}

The authors would like to correct an error in the original publication of the online article. The line appearing in the penultimate paragraph under the heading "FLCN may function in multiple signaling pathways as a tumor suppressor" has been published incorrectly.

The correct sentence should read as "They found a clear correlation between reduced FLCN expression and overexpression of the PGC-1a target gene set in a variety of tumor types."

The online version of the original article can be found under doi:10.1007/s10689-012-9574-y.

L. S. Schmidt

Basic Science Program, SAIC-Frederick, Inc., Frederick

National Laboratory for Cancer Research, Frederick, MD, USA

L. S. Schmidt $(\bowtie)$

Urologic Oncology Branch, National Cancer Institute, NIH,

Bldg 10/CRC/Rm 1-3961, 10 Center Drive MSC 1107,

Bethesda, MD 20892, USA

e-mail: schmidtl@mail.nih.gov 